\title{
Synthetic Biology: opportunities for Chilean bioindustry and education
}

\author{
Fernán Federici ${ }^{1,2}$, Timothy J Rudge ${ }^{1}$, Bernardo Pollak ${ }^{2}$, Jim Haseloff ${ }^{1}$, Rodrigo A. Gutiérrez ${ }^{2}$ \\ Department of Plant Sciences, University of Cambridge, Cambridge, UK. \\ 2 Departamento de Genética Molecular y Microbiología. Pontificia Universidad Católica de Chile. \\ Center for Genome Regulation. Millennium Nucleus Center for Plant Functional Genomics.
}

\begin{abstract}
In an age of pressing challenges for sustainable production of energy and food, the new field of Synthetic Biology has emerged as a promising approach to engineer biological systems. Synthetic Biology is formulating the design principles to engineer affordable, scalable, predictable and robust functions in biological systems. In addition to efficient transfer of evolved traits from one organism to another, Synthetic Biology offers a new and radical approach to bottom-up engineering of sensors, actuators, dynamical controllers and the biological chassis they are embedded in. Because it abstracts much of the mechanistic details underlying biological component behavior, Synthetic Biology methods and resources can be readily used by interdisciplinary teams to tackle complex problems. In addition, the advent of robust new methods for the assembly of large genetic circuits enables teaching Biology and Bioengineering in a learningby-making fashion for diverse backgrounds at the graduate, undergraduate and high school levels. Synthetic Biology offers unique opportunities to empower interdisciplinary training, research and industrial development in Chile for a technology that promises a significant role in this century's economy.
\end{abstract}

Key terms: Synthetic biology, bioengineering, education, engineering, biotechnology.

\section{WHAT IS SYNTHETIC BIOLOGY?}

Over a century ago, a paradigm shift in the physical sciences, triggered mainly by pioneering work from Georg $\mathrm{Ohm}$, Michael Faraday and James Maxwell, resulted in the emergence of the electrical engineering discipline and its applications. In the same way electrical engineers formulated rules and methods to manipulate natural electromagnetic phenomena, synthetic biologists are attempting to establish design principles for the engineering of biological machines and systems.

Synthetic Biology emphasizes the use of well characterized building blocks and mathematical modeling for predictable design, and aims to minimize the need for ad hoc approaches, iterative debugging and troubleshooting (Smolke and Silver, 2011). For example, although artificial genetic switches had already been developed in the 1980's (Podhajska et al., 1985), pioneering work by Elowitz et al. (2000) and Gardner et al. (2000) led to the realization of predictable programming of more elaborated dynamical processes in cells (McAdams and Arkin, 2000). The idea that biological systems could be treated as reprogrammable material has led to the exploration of a wide variety of applications. These have ranged from multi-chromatic bacterial photo-films (Levskaya et al., 2005; Tabor et al., 2011) to in vivo cell-type classifiers that recognize molecular profiles in cancer cells (Xie et al., 2011). Synthetic Biology is catalyzing new approaches in biotechnology (Khalil and Collins, 2010), medicine (Ruder et al., 2011; Weber and Fussenegger 2011) and scientific research (Elowitz and Lim, 2010; Mukherji and van Oudenaarden, 2012; Nandagopal and Elowitz, 2011). Projects such as the synthesis of artificial genomes (Gibson et al. 2010), genome-wide DNA editing
(Esvelt and Wang, 2013); artificial proto-cells (Mansy et al., 2008; Hammer and Kamat, 2012), reprogrammed genetic code (Chin, 2012); in vivo numerical computation (Benenson et al., 2011; 2012); nano-robots (Douglas et al., 2012); and digital data storage in DNA (Church et al., 2012); are changing our perception of biology from a mere source of raw materials to a programmable medium for manipulating matter and information.

\subsection{Enabling technologies: DNA synthesis and assembly}

Whereas traditional genetic engineering uses recombinant DNA technologies for reading, amplifying, cutting and pasting DNA templates from one organism to another, Synthetic Biology exploits large scale chemical synthesis of custom-defined DNA sequences (Carlson, 2009; Baker,2011) and high-throughput methods for DNA assembly (Ellis et al., 2011). These technologies have not only expanded the size of manufactured DNA fragments to the scale of megabases, enough for the synthesis of a whole synthetic genome (Gibson et al., 2010) or a book of 53,426 words (Church et al., 2012), but also provide an unprecedented capability for template-free DNA manufacture that allows arbitrary genetic information to be constructed from the bottom-up. However, these advances have largely surpassed the genetic engineer's ability to rationally design functioning genetic circuits at large scale, creating a "design gap" between the enabling technologies and the knowledge to engineer de novo high order biological functions. One of the major challenges of Synthetic Biology is to formulate the methods and design principles that bridge this gap (Smolke and Silver, 2011). 


\subsection{Design principles: abstraction, decoupling and modularity.}

Abstraction, decoupling and modular design have been key enabling concepts for engineering, allowing the design of systems in which millions of components are combined to produce predictable behaviors. For example at CERN (http:// home.web.cern.ch), physicists and engineers have built the LHC (Large Hadron Collider), a $27 \mathrm{~km}$ long structure that can accelerate particles close to the speed of light and collide them with a precision equivalent to shooting two needles from $10 \mathrm{~km}$ apart. This precision is only possible because the parts are well defined, characterized and modular, allowing their collective behavior to be predicted. Similarly, efforts are beginning to define reliable building blocks for biological engineering (Kosuri et al., 2013; Davis et al., 2011, Mutalik et al., 2013a; 2013b; Liu et al., 2012; Lou et al., 2012; Qi et al., 2012). The Synthetic Biology community has grown around the goal of implementing standardized modular building blocks to construct genetic circuitry (Knight, 2003; Endy, 2005; Shetty et al., 2008; Canton et al. 2008). The aim is to create "off-the-shell" biological parts that can be used to design at a higher level of abstraction. This idea led to the creation of the MIT-based Registry of Standard Biological Parts (www.partsregistry.org) that lists and distributes thousands of widely used genetic building blocks.

Abstraction means incorporating detailed information about individual components into simplified representations of their behavior. These abstract parts can then be used to design sub-systems, which are again abstracted (Fig. 1A). For example, genetic elements can be combined to create devices that encapsulate certain biological functions (e.g. invert a signal or communicate with another cell). In this way, hierarchical layers of abstraction enable design of large scale systems (Tabor et al., 2009; Andrianantoandro et al., 2006; Endy, 2005; Canton et al., 2008). The use of these standards and abstractions, in combination with DNA synthesis on demand, would lead to decoupling of high level design tasks from lower level specifications and parts fabrication (Fig. 1A). This approach should allow re-use of components and devices in multiple systems given standards for the definition, description and characterization of genetic building blocks (Endy, 2005) (Fig. 1B).

The concepts of modularity, and hierarchies of modules, have facilitated reverse engineering of naturally evolved biological processes (Lauffenburger, 2000, Nurse, 2008). This is because biological systems naturally exploit some level of modularity (Hartwell et al., 1999). Functional modularity can be identified at the molecular level (Grunberg and Serrano, 2010, Khalil et al., 2012), metabolic level (Alon, 2006) and developmental level (von Dassow et al., 2000; Espinosa-Soto and Wagner, 2010; Gallois et al., 2004, Niehrs and Meinhardt, 2002; Davidson, 2010). This modular organization has been suggested to be an adaptive trait that facilitates evolutionary exploration by allowing rewiring of existing higher level building blocks that perform modular biological functions (Hartwell et al., 1999; Lipson, 2007, Milo et al., 2002; Kashtan and Alon, 2005). This feature is reflected in the scale-free topology of gene regulatory networks (Bray, 2003; Jeong et al., 2000; Albert et al., 2000). There are however, varying degrees of modularity in natural systems, which also exploit crosstalk at different levels of hierarchically nested processes (Vilar, 2006; Weng et al., 1999). Such systems are very difficult to understand and design.

The radical aim of synthetic biology is to minimize such crosstalk and create orthogonal parts and modular functions that would facilitate human design by abstraction
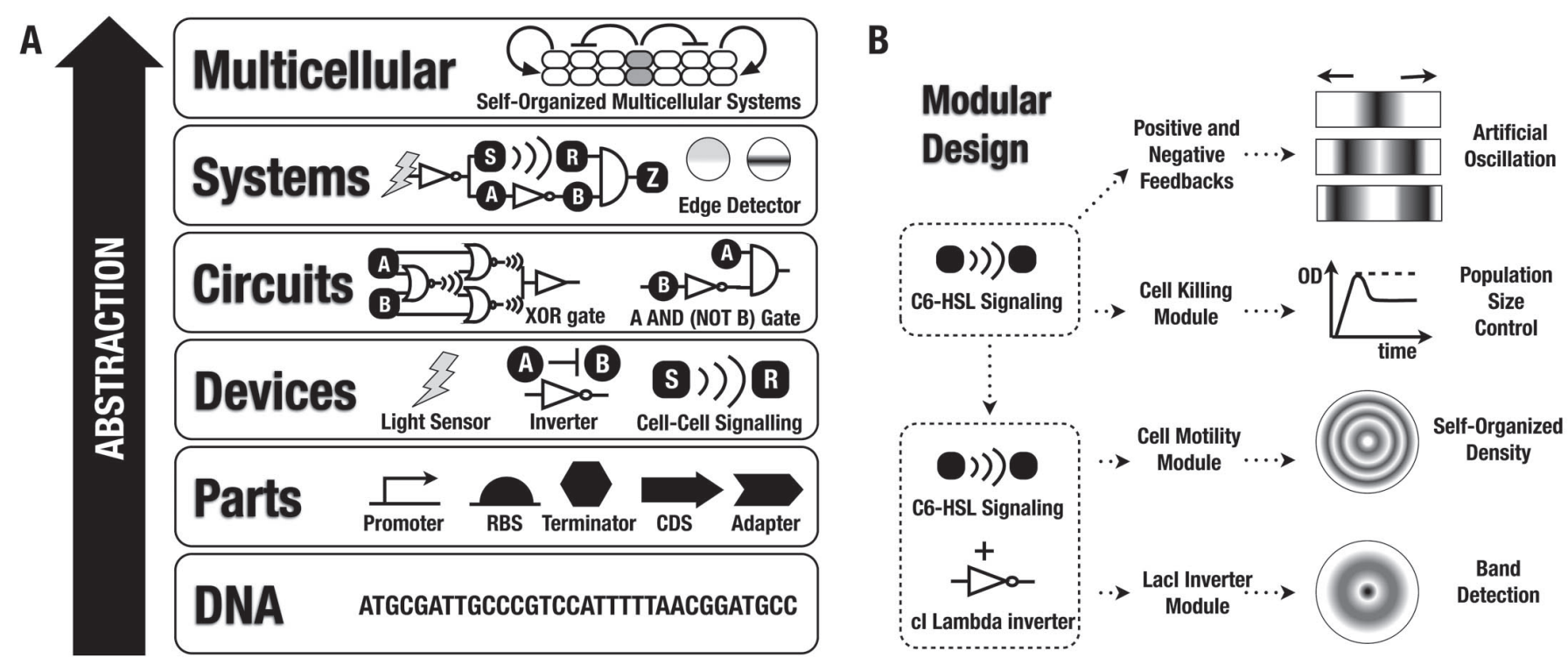

Figure 1. Design principles of Synthetic Biology. A) Abstraction hierarchy from DNA information to engineered multicellular systems. Decoupling and Abstraction (adapted from Endy, 2005). B) Modular design allow re-use of components and devices in multiple systems. For instance, C6 homoserine lactone signaling module has been used in combination with a negative feedback regulation loop for engineering traveling waves and oscillations (Danino et al., 2010), and along with a cell killing module for programming population size regulation by population size-dependent mechanisms (You et al., 2004). The combination of this module and the cl lambda inverter has been used with a cell motility module for artificial cell density regulation in space (Liu et al., 2012), and with a lacl inverter module for the construction of a band detect system (Basu et al., 2005). 
and decoupling (Andrianantoandro, et al., 2006). Recently, the NSF-funded International Open Facility Advancing Biotechnology (BioFab, www.biofab.org) was established as the first design-build facility and is specifically addressing this aim. The initiative is inspired by the microelectronics fabrication facilities which propelled the rapid expansion of the electronics industry. BioFab is designing, and performing high-throughput characterization of genetic elements and is making this data freely available to both academic and commercial users, an effort that aims to facilitate open innovation. They have already contributed critical information and solutions for creating modular transcription and translation control elements with minimum interference (Mutalik et al., 2013a; 2013b; Cambray et al., 2013).

\subsection{Parts characterization and system design}

Abstraction of biological parts relies on precise and accurate part performance and operation measurements covering the range of relevant variation. Reference standards, or special parts referred to as "yardsticks", have been proposed to reduce variation in reported part performance between labs (Kelly et al., 2009; Federici et al, 2012). In this approach, measurements can be made using different methods and equipment, and normalized with respect to the properties of the reference part measured using the same method (Kelly et al., 2009). Normalization with respect to an internal (in vivo, co-localized) reference standard could also significantly decrease variability and artifacts introduced by equipment and operational settings (Federici et al, 2012). These approaches will allow the exchange of part performance data in meaningful and comparable values. Using measurements of reference parts under different conditions and in different strains, it might also be possible to define "dynamic yardsticks" that could allow extrapolation or inference of part performance to untested conditions.

Reference part parameterizations must capture correlations in the behavior of different parts due, for example, to interactions with the cellular environment. This interaction with the cellular context is a major challenge in designing engineered genetic circuits (Cardinale 2012). Even well understood mechanical structural systems can suffer from the unpredictable emergence of context-dependent behaviors (e.g. pedestrian-induced vibration in the Millennium Bridge, London; Dallard et al., 2001). Synthetic circuits can be influenced by extrinsic noise (Elowitz et al, 2002; Swain et al., 2002) arising from context-dependent mechanisms such as metabolic load (Neubauer et al., 2003), fluctuations in rates of component degradation (Cookson et al., 2011) and growth changes (Klumpp et al., 2009). Novel computational methods and genetic techniques (Elowitz 2002, Federici et al., 2012; Hilfinger at al., 2011; Berthoumieux 2013) have been developed to extract the effect of extrinsic noise such as variation arising from growth rates (Berthoumieux 2013). The combination of these measurement techniques with observations in highly controlled micro-fluidic environments (Bennett and Hasty, 2009) could lead to better understanding of extrinsic effects on part performance.

A major motivation for accurate measurement of genetic part behavior is to facilitate predictive mathematical modeling. The use of in vivo fluorescent markers, in combination with mathematical descriptions, has been critical to deriving estimates of underlying mechanisms, such as transcription rates (De Jong et al., 2010; Leveau et al., 2001; Kelly et al., 2009; Munsky et al., 2012), parameters of induction/repression, and translation efficiency (Salis et al., 2009). In most cases, these estimates are indirect measurements in arbitrary units because the fluorescence level is used as a proxy for underlying processes that are not accessible to measurement. In some cases, direct measurements can be made, for instance, single molecule fluorescence in situ hybridization (smFISH) has been used to observe mRNA distribution in individual cells and study changes in transcription over time (So et al., 2011). However, in general it is not possible to measure all the parameters of interest, and it is usually necessary to use rough estimates of parameters and consider their variance (e.g. Basu et al, 2005). An alternative is to consider the plausible range of parameters, and to test a large random sampling of these distributions (Ma et al., 2009, Cotterell et al., 2010). This might lead to a design approach which is not strictly predictive, but that guides construction with estimates of the statistical likelihood of a particular system operating as desired.

Mathematical models of genetic parts, parameterized by measurements, can then be used to derive the dynamics of assemblies or systems (Elowitz et al., 2000; Gardner et al., 2000) and incorporate into simulations. Measurement of the composed system in operation then informs further measurement and refined modeling by comparison to simulations. An interesting example is the transcriptional oscillator (Danino et al., 2010). During the development of this system, it was found that delays generated by queueing for degradation (Cookson et al., 2011) were essential to generate oscillations, which led to further investigation and measurement of these effects, as well as incorporation into models.

Capturing statistical properties, and cell to cell variability of part behavior is important, especially since there are cases where this can lead to unexpected effects (Samoilov et al., 2006,; Neuert et al., 2013). Studies of such effects have been performed using time-lapse microscopy to track reporters in individual cells (Young et al., 2011), using synthetic constructs to analyze the stochasticity in transcription and translation (Swain et al., 2002; Munsky et al., 2012). Stochastic simulations can capture individual cell dynamics, for example using Monte Carlo methods (Gillespie, 1977) or Finite State Projection a more efficient method that estimates the probability distribution of the system state at each time (Munsky et al., 2006; Munsky et al., 2012; Lou et al., 2012). Data from these simulations can be compared to the distributions of reporters within populations, generated by flow cytometry (FACS), to validate underlying models (Lou et al., 2012). Using microfluidic devices, large amounts of data can now also be captured for individual cells over long periods (e.g. Wang et al., 2010; Long et al., 2013), and in combination with inference methods (Neuert et al., 2013) should lead to increasingly predictive models that incorporate stochasticity and other sources of variation.

For predictive modeling, cell growth and division adds another level of dynamics in space and time, which in multicellular systems can contribute significantly to system behavior, e.g. through cell-cell signaling (Danino et al., 2010). Computational modeling of biophysical interactions between cells combined with simple experiments (Volfson et al., 2008; Boyer et al., 2011; Rudge et al., 2012) is beginning to reveal 
mechanisms of cellular organization. The recent development of large scale parallel processing architectures (Graphics Processor Units) in low cost, commodity hardware has allowed these models to scale to hundreds of thousands of cells (Rudge et al., 2012). Combined with accurate measurements facilitated by microfluidic devices (Wang et al.,2010) this opens up the possibility of large scale predictive modeling of multicellular systems on desktop computers.

The availability of measured genetic components, cell growth and division, and mathematical models of them, could give rise to effective automated design methodologies (Rodrigo et al., 2011; 2012; Yaman et al., 2012; Beal et al., 2012) that would naturally combine with automated DNA assembly to ease the implementation of genetic designs (Densmore, 2012). For instance, CAD (Computer Aided Design) approaches to compiling high level specification to DNA parts (Chandran and Sauro, 2012; Yaman et al 2012; Beal et al., 2012) are being developed in anticipation of libraries of parts, and could be combined with optimization tools, such as genetic algorithms (Chang et al., 2013).

\section{IMPLEMENTATION}

Progress on enabling technologies and methods is leading to a transition in the field from the engineering of small proof-ofprinciple devices such as switches, oscillators and time-delay circuits to the generation of more elaborate systems with a desirable function (Purnick and Weiss, 2009, Lu et al., 2009). This advance can be broadly split in two areas: i) mechanisms for sensing and processing of information, and ii) engineered processes and metabolic optimization as outputs.

\subsection{Information processing}

The main approach to engineering information processing in biological systems has been boolean logic, concerned with component states that are either "on" or "off" according to certain thresholds (Miyamoto et al., 2012, Weiss et al., 2003). Inspired by the critical role of boolean abstractions in the development of electronics, the resemblance of genetic networks to electrical circuits (McAdams and Shapiro, 1995), and the early application of boolean analysis to genetic regulation (Sugita, 1963; Kauffman, 1969, Thomas, 1973), the synthetic biology field has adopted a similar approach to forward engineering genetic circuits. Although a simplified view, the boolean abstraction has served to understand gene regulatory networks since the early studies on transcriptional regulation pioneered by Jacob and Monod (1961), and continues to be useful today (Peter et al., 2012; Albert and Othmer, 2003; Mendoza et. al., 1999; Espinosa-Soto et al., 2004; Li et al., 2004).

The aim of implementing boolean logic schemes in engineered cells is not to compete with silicon-based technologies, but to program molecular systems to sense, process and respond in vivo and at nano scale to certain signal profiles, such as from cancer cells (Douglas et al., 2012; Xie et al., 2011). The approach has led to the design of all possible two-input boolean logic functions (e.g. NOR gates, Tamsir et al., 2010; Win and Smolke, 2008) and higher order information processing functions (Moon et al., 2012). Applications ranging from biosensing (Rinaudo et al., 2007, Wang et al., 2013) to arithmetic operations in mammalian cells
(Auslander et al., 2012) have demonstrated the scope and potential of boolean systems for the implementation of humanprogrammable decision-making networks in cells. Techniques for implementing boolean logic have included transcription and translation regulation (Tamsir et al., 2010, Liu et al., 2012), protein switches (Grunberg and Serrano, 2010; Dueber et al., 2003), as well as recombinase (Siuti et al., 2013) and integrase enzymes (Bonnet et al., 2012; 2013).

To achieve engineered logic-based decision making as complex as natural systems would require a very large set of orthogonal components-parts which do not interfere with each other. As opposed to electronic circuits where crosstalk is avoided by an spatial distribution of components; cells rely on chemical specificity and differential affinity for chemical isolation (Hartwell et al., 1999). The distribution of elements in the cell forces the components to be chemically isolated from each other. This problem has been tackled by separation of gates in different bacterial colonies and the use of diffusible signals to link them (Tamsir et al., 2010), and inspiration from distributed computing (Regot et al., 2011). Recent work (Liu et al., 2012) has developed orthogonal RNA-based transcription and translation regulators, and used them to compose NOR gate-based regulatory functions in single cells. The number of orthogonal parts could also be increased by computational protein design (Van der Sloot et al., 2009; Jiang et al., 2008; Röthlisberger et al., 2008); protein shuffling (Grunberg and Serrano, 2010); directed evolution (Moon et al., 2012), rational design of DNA-protein interactions (e.g.TAL effectors, Garg et al., 2012; Boch et al., 2009; Blount et al., 2012), RNA-based protein-DNA interaction (e.g CRISPR, Farzadfard et al, 2013) and complete orthogonal transcription and translation mechanisms (An and Chin, 2009).

DNA computing is another approach with promising prospects for implementing information processing in cells (Benenson, 2011). Based on DNA displacement reaction mechanisms, this method has been used to perform logical and numerical operations (Qian and Winfree, 2011), and can achieve modularity and orthogonality through DNA sequence specificity. DNA molecules also have the advantage of coupling information processing and mechanical behaviour, allowing sensing, processing and actuation to be performed by the same type of molecules at nano-scale. This feature has been exploited to create nano-structures whose cargo release depends on DNA sequence-specific unlocking (Andersen et al., 2009) and aptamer-gated control (Douglas et al., 2012).

A complementary approach to tackle issues of orthogonality and number of parts is the use of feedback mechanisms in simpler designs inspired by naturally evolved systems. Simpler circuitry, in combination with cell-cell signaling, nonlinear reactions and the stochastic nature of gene expression, give rise to the emergence of complex biological phenomena such as morphogenesis (Turing, 1952, Gierer and Meinhardt, 1972) and cell differentiation (Suel et al., 2006: Maamar et al., 2007; Cagatay et al., 2009). Small genetic regulatory circuits exhibiting nonlinear behavior and multiple states, such as those found in metabolic networks (Ozbudak et al., 2004) and morphogen interpretation (Kicheva et al., 2012), could aid in the engineering of complex information processing schemes with simpler implementations. The use of feedbacks, a critical mechanism for many biological processes (Ferrel et al., 2002); has already enabled the development of complex systems such as oscillators and traveling waves of 
gene expression (Danino et al., 2010), switches (Gardner et al., 2000), and excitable media (Suel et al., 2006). Information processing challenges in other fields have already found inspiration in the non-linear, highly parallel and selforganizing mechanisms of biological systems such as social insect behavior (Bonabeau et al., 2000), neural organization (Hopfield,1982), tissue patterning (Afek et al., 2011), and slime mold foraging strategies (Tero et al., 2010, Fratzl et al., 2007, Adamatzky and Jones, 2010).

Re-applying these concepts to the engineering of biological systems, engineering biology with biology, could shed light on the engineering of decentralized decision-making mechanisms, self-assembly and robustness in engineered systems. For instance, the dissection of input-output relationships in bacterial chemotaxis (Barkai and Leibler, 1997; Alon 1999; Yi et al., 2000) and animal development (Goentoro et al., 2009; Goentoro and Kirschner 2009; Cohen-Saidon et al., 2009) could provide a blueprint for implementing fault-tolerance in man-made biological systems. Systems Biology is starting to catalog the motifs (Shen-Orr et al., 2002) and identify the topologies that underlie robust behavior (Hartwell, 1997; Yi et al., 2000; Kitano, 2007; Shinar and Feinberg, 2010; Barkai and Leibler, 1997; Stelling 2004; Jeong et al., 2000; Albert et al., 2000; Balaji et al., 2006). These could be abstracted and used as modular core functions in engineered higher order implementations (Lim et al., 2013) and rewired under certain objective function constraints to direct the evolution of desired performance. A recent innovation is the application of principles from analog computing to engineer regulatory networks to perform continuous valued (rather than digital or binary) transformations of inputs such as arithmetic operations (Ramiz et al., 2013).

\subsection{Output}

Complete sense-and-respond functional systems and applications have emerged from the interfacing of the signal processing mechanisms described above with output processes of interest. For instance, cells have been engineered to maintain uric acid homeostasis (Kemmer et al., 2010). target human pathogens (Saeidi et al., 2011) and invade cancer cells (Anderson et al., 2006).

An area of increasing interest is the programming of emergent behavior and self-organizing processes in multicellular systems and consortia (Shong et al., 2012). The implementation of artificial cell-cell communication mechanisms in bacteria (Bulter et al., 2004; Brenner et al., 2007; Basu et al., 2005), yeast (Chen and Weiss, 2005) and mammalian cells (Wang et al., 2008) has been exploited to engineer collective behavior (You et al., 2004; Liu et al.; 2011; Danino et al., 2010). For instance, Wu et al. (2013) engineered mammalian cancer cells to produce a quorum sensing signal (AI-2), and concurrently created a strain of AI-2 responsive $E$ coli. The bacteria were further engineered by coupling the AI-2 response to their native chemotaxis system, causing them to migrate towards nearby mammalian cells, and also produce a fluorescent protein signal. Hence two natural bacterial behaviors (quorum sensing and chemotaxis) were combined with engineered regulatory networks to produce a useful functional output - aggregation of fluorescent bacteria on cancer cells.
The engineering of multicellular populations could lead to the programming of pattern formation, artificial cell consortia and synthetic ecosystems (Brenner et al., 2008, Brenner and Arnold, 2011, Shou et al., 2007; Wintermute and Silver, 2010; Chuang, 2012). The establishment and maintenance of distinct cohorts of cells might be used for example to facilitate the optimization of metabolic pathways by separating inhibitory intermediate metabolites. Multicellular and colonial systems exploit cell differentiation for the compartmentalization of tasks, for instance the $\mathrm{C} 4$ photosynthesis system improves enzymatic efficiency by delegating different steps to distinct leaf cell-types. The use of artificial cell-cell communication, symmetry-breaking mechanisms (Turing, 1952; Gierer and Meinhardt 1972), cell-type domain maintenance (Perales and Reddy, 2012), mechanical cell interaction (Rudge et al, 2012; Boudaoud et al., 2010), and growth (Liu et al., 2011) could lead to the development of self-organized, distributed systems such as morphogenesis. The rewiring of modular cellular behaviors in multicellular systems would add an extra layer of abstraction to synthetic biology (Fig. 1A).

\section{MODELING BIOLOGY WITH BIOLOGY: AN APPROACH TO ACCELERATING BIOLOGICAL RESEARCH}

In addition to the benefits for technology, Synthetic Biology is helping biological researchers to gain a better understanding of living organisms (Bashor et al., 2010; Isaacs et al., 2003). Synthetic circuits have already provided insights into the functioning of natural processes such as mechanisms of evolution and selection (Chuang et al., 2009; Chuang et al., 2010; Sekine et al., 2011); population dynamics (Weber et al., 2007; Balagadde et al., 2008; Tanouchi et al., 2012); stochastic processes in molecular networks (Pedraza and van Oudenaarden, 2005; Elowitz et al., 2002; Blake et al., 2003); robustness and performance of gene regulation (Damle and Davidson 2012; Becskei and Serrano, 2000; Cantone et al., 2009; Isaacs et al., 2003); animal physiology (Chow and Boyden, 2011); signaling mechanisms in immune cells (Schamel and Reth, 2012); and genome-wide network evolvability (Isalan et al., 2008). Reconstituting natural systems; modeling biology with biology, is refining reverse engineering tools (Cantone et al., 2009) and helping in the study of fundamental question in biology (Liu and Fletcher, 2009). The assembly of dynamical biological systems will aid the transition from research focused on individual molecules, which dominated twentieth-century biology, to a more holistic perspective such as the approach proposed by Systems Biology (Hartwell et al., 1999).

A profitable relationship is already growing between Systems and Synthetic Biology (Lanza et al., 2012) (Fig. 2). Both fields share a view of biology based on dynamical systems, rather than isolated genes, and see similar challenges in obtaining accurate measurements, recognizing the important parameters to measure, and integrating these values into higher-order abstractions (Smolke and Silver, 2011). The use of forward and reverse engineering approaches in combination with machine learning tools (Bongard et al., 2006; Bongard and Lipson, 2007; Schmidt et al., 2009; Schmidt et al., 2011) could lead to new ways of modeling and understanding biological phenomena as well as refining the design principles of Synthetic Biology. Applying the design-build-test cycle of synthetic biology to Systems Biology would benefit both hypothesis-driven experiments and forward engineering of 

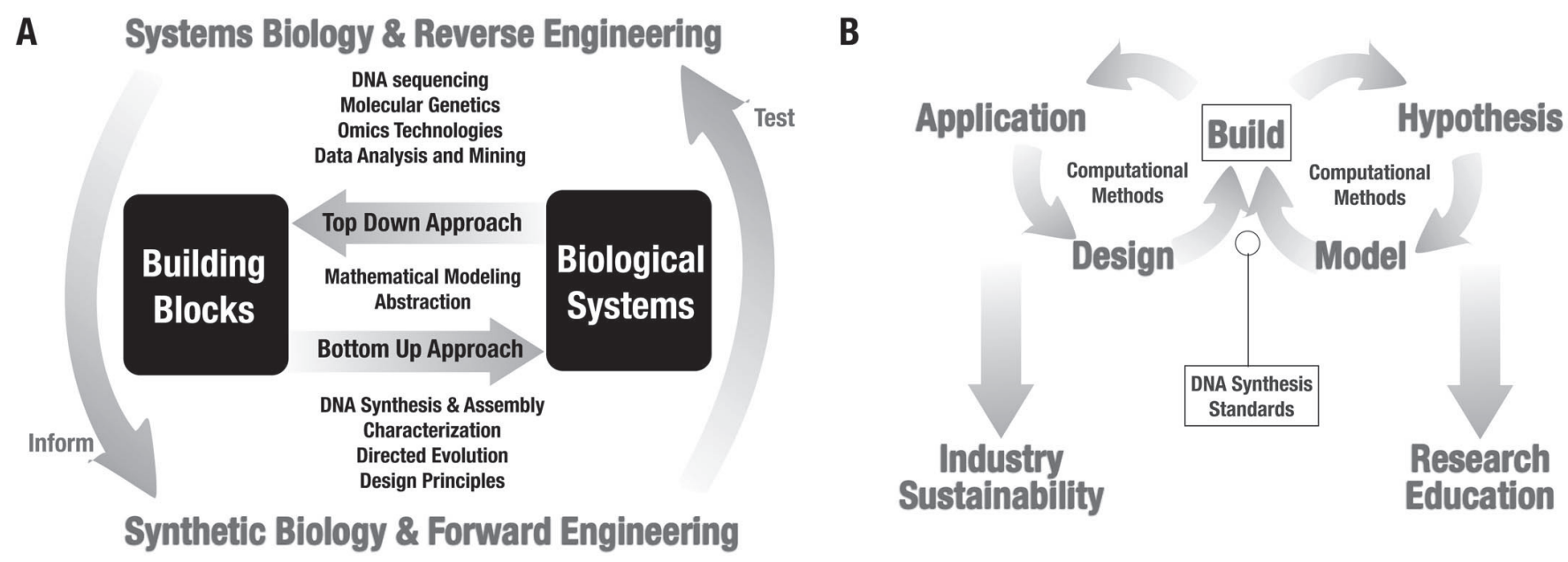

Figure 2. Synergy between Synthetic and Systems Biology. A) Systems Biology and its methods can inform the design process of Synthetic Biology and provide new parts and network motifs; whereas Synthetic Biology and its tools can benchmark Systems Biology tools and test its models by rewiring and refactoring natural systems. Abstraction and mathematical modeling are key tools for the systematic analysis of naturally evolved systems as well as the engineering of artificial biological functions. B) The advent of large scale DNA synthesis technologies and the development of standard for bioengineering will accelerate forward and reverse engineering cycles through faster and more predictable ability to build large genetic systems. These improvements will boost the industry, educational programs and scientific research.

biology (Fig. 2B). Thus, Systems and Synthetic Biology can both gain from each other's resources and methods (Smolke and Silver, 2011; Lim et al., 2013).

\section{LEARNING BY MAKING: A NEW PERSPECTIVE FOR TEACH- ING BIOLOGICAL SCIENCES AND BIOENGINEERING}

With decreasing costs in DNA manufacturing technologies, innovation and entrepreneurship in Synthetic Biology becomes accessible not through infrastructure, but mainly through knowledge and human capital. Therefore, developing Chile's future human capital through new educational programs results crucial to play a major role in the future development of bio-economies. Synthetic Biology and its more reliable methods are already transforming educational programs (Elowitz and Lim, 2010). With a radical shift towards "learning by making", the refactoring of biological sub-systems represents a more engaging approach for teaching Biology and Bioengineering. This idea has already given rise to an innovative educational program, namely the international Genetically Engineered Machine competition (iGEM) (Smolke, 2009). This is an international contest in Synthetic Biology for undergraduate students, with participants from more than 180 different universities. iGEM is held in the spirit of robotics competitions in engineering fields, except that the students face the challenge of conceiving, designing and implementing a synthetic biological system and operating it in living cells. Open access to a collection of genetic parts, robust assembly methods for the construction of devices, user experience information regarding device implementations and parts performance, and a community repository of experimental protocols (www.openwetware.org) has significantly eased the construction of genetic systems. More efficient methods of DNA assembly and the abstraction of lower level DNA details allow students to focus on system design and modeling, and not on manufacturing the basic building blocks. A clear indication of the potential of these enabling tools is the fact that in just 12 weeks, students with no previous experience in molecular biology have assembled novel biological systems such as bacterial photo-films (Levskaya et al., 2005) and spatiotemporal patterning mechanisms (Liu et al., 2011). P. Universidad Católica de Chile sponsored the first Chilean iGEM team in 2012 (www.igemuc.cl), which was selected in the Latin American regional final to compete in the grand final at MIT. More Chilean teams are expected this year and further support to these initiatives will undoubtedly contribute to the creation of the human capital and infrastructure required for engaging Chile with a promising technology and its nascent economy.

\section{LEGAL, ETHICAL AND SOCIAL CONSIDERATIONS}

The application of Synthetic Biology will produce recombinant organisms that could be used in large-scale contained use, biomedical therapies or for field release. The new technology has great potential to provide substantial benefits for human health, nutrition and sustainable industrial practices. However, as our ability to manipulate DNA and engineer new biological systems advances, so does concern about the impact (due to unforeseen consequences or human error) that new organisms may have on our environment. Most surveys of the potential risks associated with Synthetic Biology (e.g. New Directions: The Ethics of Synthetic Biology and Emerging Technologies. 2010; http:// bioethics.gov/synthetic-biology-report) have recognized the similarity of the technology with existing approaches that use organisms with genetic modifications (e.g. transgenic crops). As for genetically modified organisms, the main areas of concern are (i) the dangers of environmental release of genetically modified organisms due to invasive growth or predation, (ii) unforeseen problems for human or 
animal health through consumption or exposure to genetically modified products, and (iii) inequities that might arise through concentration of ownership and control of the new technologies by a few corporations. At this time, anticipated Synthetic Biology products fall within the scope of existing regulations and practices for handling genetically modified organisms.

However there is a recognized need to maintain a watching brief on development of the technology, and to ensure that existing regulatory systems are revised to take account of future developments in the field. Those who find the use of genetically modified organisms unacceptable, find similar concerns with the application of Synthetic Biology. A coalition of non-governmental organizations have called for a moratorium on the release and commercial use of Synthetic Biology products (The Principles for the Oversight of Synthetic Biology, 2012). In contrast, corporations and their lobbyists are keen to explore applications of the technology, and vigorous debate is in progress. The international scientific community has played a substantive role in this debate, promoting discussion of the practical potential and ethical implications for the technology, and contributing to policy development internationally. This healthy debate is likely to continue, as the field continues to develop, and we can better evaluate its potential contribution to improvement of sustainable practices for agriculture, production and conservation, and balance these factors with risks due to the new technology, and existing unsustainable practices. Chile should promote similar discussions and debate to generate an adequate legal framework and regulatory system for Synthetic Biology as well as other technologies that use genetically modified organisms.

The engineering of living systems has raised issues around ownership of the technology. Current business practices in biotechnology promote patent protection of all key innovations. The securing of intellectual property is crucial for company investment, licensing income and freedom to operate in the market. Restrictive licensing practices and patent protection are often used as tools to secure market share, as well as to protect a company's investment in innovation. Synthetic Biology offers the prospect of large-scale reprogramming of living systems, but this will require access to relatively large numbers of components. This is in contrast to existing GM products that contain one or a few components. There is growing requirement for libraries of well characterized routine components that can be shared for the construction of a variety of systems, where small companies would be ensured freedom to operate. This is essential to foster the kind of innovation seen at the emergence of other new technologies such as microelectronics and software development.

Accordingly, a substantial part of the Synthetic Biology field has promoted open standards and sharing of data and resources, inspired by the open source software movement. The educational community has embraced the open source principle in the establishment of the MIT Registry of Standard Parts, which is widely and freely distributed internationally, and grows year-on-year. The BioBricks Foundation is a non-profit organization which has roots in the academic community, and which has promoted a legal framework which would allow protection of Synthetic Biology applications and key activities, but which would facilitate sharing of parts. The UC Berkeley-Stanford BioFab recently made the sequences and measurement data for its collection of parts available online.
These kinds of resources are precious, enabling freedom to operate for individual inventors, entrepreneurs and small companies. However these resources are also fragile, and as commercial interest increases, the pressure to restrict access to innovations and new resources will rise. It is therefore important to consider the legal framework for protection of intellectual property and the types of institutions gathering and storing data on biological resources, in order to foster open innovation. Maintaining a decentralized, globally accessible, and open database of parts would foster access to these new technologies outside elite research institutions and large biotechnology corporations. Advances in DNA synthesis technology, that decouple DNA-encoded biological information from its physical DNA substrate, allow engineers to reconstitute functional genetic devices anywhere in the world by 'compiling' digital information. Maintaining open access to this digital information would make the technology inherently low cost; leading to a knowledge-based economy with obvious applications in developing countries.

\section{FUTURE PROSPECTS FOR CHILE: PROGRAMMING BIOLOGY AND POTENTIAL APPLICATIONS TO CHILEAN INDUSTRY}

Synthetic biology could benefit Chile and other Latin American countries by boosting existing bio-industrial platforms with more reliable tools and methods, and opening a new horizon for biotechnological applications. The World Economic Forum placed synthetic biology at the forefront of the coming century's economic agenda (World Economic Forum Global Agenda Council on Emerging Technologies, 2012). It has also been made a priority by the US government as a key area for the transition to the bio-economy (National Bioeconomy Blueprint). Recent developments such as the production of antimalarial drug precursor artemisinin in microbes (Ro et al., 2006; Peplow, 2013), the refactoring of a nitrogen fixation pathway (Temme et al., 2012) and the production of biofuel and chemicals (McEwen and Atsumi, 2012) with engineered microbes have shown the potential of synthetic biology for the generation of drugs, new compounds as well as renewable resources. Advances in the design of robust genetic circuits and systems will lead to faster, affordable and more efficient development of such applications.

Most biotechnological developments rely on the modification of existing natural components such as the recent generation of genome editing tools based on mechanisms of Xanthomona's infection of plants (Garg et al., 2012; Boch et al., 2009; Moscou et al., 2009; Blount et al., 2012). Chile has a unique opportunity to contribute to expanding this repertoire of biological components, processes and chassis by tapping into its genetic biodiversity. Chile's geography constitutes an advantage by spanning a wide range of climates and environments from antarctic to desert ecosystems. For instance, the Atacama desert, the driest desert on earth, contains unique microorganisms and plants adapted to harsh environmental conditions (Navarro-Gonzalez et al., 2003; Drees et al., 2006; Villagran et al., 1981). Mining this biodiversity for the development of novel sensors, actuators, effectors and other parts is possible if funding programs for exploratory or catalog type research projects are established in Chile. The re-engineering of these natural biological functions could generate new industries and have a great economic 
impact in the region. A single engineered enzyme used in laundry detergents that can reduce hot water energy use by the equivalent of 100.000 barrels of oil a day in the US (http:/ / democrats.energycommerce.house.gov/documents / 20100527 / Endy.Testimony.05.27.2010.pdf). Chile is currently supporting innovation and entrepreneurship (Orellana, 2004), however a great deal of work is necessary to generate the tools and building blocks necessary for new Synthetic Biology-based biotechnologies. We currently have significant support for basic and applied research programs. Complementing these efforts with technology funding programs will guarantee the generation of sufficient parts, devices and circuits for developing Synthetic Biology applications.

\section{ACKNOWLEDGEMENTS}

Research in our group is funded by International Early Career Scientist program from Howard Hughes Medical Institute, Fondo de Desarrollo de Areas Prioritarias (FONDAP) Center for Genome Regulation (15090007), Millennium Nucleus Center for Plant Functional Genomics (P10-062-F), Fondo Nacional de Desarrollo Científico y Tecnológico (1100698), Comisión Nacional de Investigación Científica y TecnológicaANR program (ANR-007). FF was supported by Gates Cambridge Scholarship and a joint EPSRC and NSF research grant (EP/H019162/1) to JH. TJR is supported by a Microsoft Research Studentship. FF was supported by Gates Cambridge Scholarship, CONICYT-PAI/Concurso Nacional de Apoyo al Retorno de Investigadores/as desde el Extranjero Folio 82130027, and joint EPSRC and NSF research grant (EP/ H019162/1) to JH. TJR is supported by a Microsoft Research Studentship.

\section{REFERENCES}

ADAMATZKY A, JONES J (2010) Road planning with slime mould: if Physarum built motorways it would route M6/M74 through Newcastle. International Journal of Bifurcation and Chaos 20:3065-3084.

AFEK Y, ALON N, BARAD O, HORNSTEIN E, BARKAI N, BAR-JOSEPH Z (2011) A biological solution to a fundamental distributed computing problem. Science's STKE 331:183.

ALBERT R, JEONG H, BARABÁSI A-L (2000) Error and attack tolerance of complex networks. Nature 406:378-382.

ALBERT R, OTHMER HG (2003) The topology of the regulatory interactions predics the expression pattern of the segment polarity genes in drosophila melanogaster. arXiv preprint q-bio/0311019

ALON U (2006) An introduction to systems biology: design principles of biological circuits Chapman \& Hall /CRC

ALON U, SURETTE MG, BARKAI N, LEIBLER S (1999) Robustness in bacterial chemotaxis. Nature 397:168-171.

AN W, CHIN JW (2009) Synthesis of orthogonal transcription-translation networks. Proceedings of the National Academy of Sciences 106:8477-8482.

ANDERSEN ES, DONG M, NIELSEN MM, JAHN K, SUBRAMANI R, MAMDOUH W, GOLAS MM, SANDER B, STARK H, OLIVEIRA CL (2009) Self-assembly of a nanoscale DNA box with a controllable lid. Nature 459:73-76.

ANDERSON JC, CLARKE EJ, ARKIN AP, VOIGT CA (2006) Environmentally controlled invasion of cancer cells by engineered bacteria. Journal of molecular biology 355:619-627.

ANDRIANANTOANDRO E, BASU S, KARIG DK, WEISS R (2006) Synthetic biology: new engineering rules for an emerging discipline. Molecular systems biology 2:

AUSLÄNDER S, AUSLÄNDER D, MÜLLER M, WIELAND M, FUSSENEGGER M (2012) Programmable single-cell mammalian biocomputers.. Nature 487:123-7.

BAKER M (2011) Synthetic genomes: The next step for the synthetic genome.. Nature 473:403, 405-8.
BALAGADDÉ FK, SONG H, OZAKI J, COLLINS CH, BARNET M, ARNOLD FH, QUAKE SR, YOU L (2008) A synthetic Escherichia coli predator--prey ecosystem. Molecular systems biology 4:

BALAJI S, IYER LM, ARAVIND L, BABU MM (2006) Uncovering a hidden distributed architecture behind scale-free transcriptional regulatory networks. Journal of molecular biology 360:204-212.

BARKAI N, LEIBLER S (1997) Robustness in simple biochemical networks.. Nature 387:913-7.

BASHOR CJ, HORWITZ AA, PEISAJOVICH SG, LIM WA (2010) Rewiring cells: synthetic biology as a tool to interrogate the organizational principles of living systems. Annual review of biophysics 39:515.

BASU S, GERCHMAN Y, COLLINS CH, ARNOLD FH, WEISS R (2005) A synthetic multicellular system for programmed pattern formation. Nature 434:1130-1134.

BASU S, MEHREJA R, THIBERGE S, CHEN M-T, WEISS R (2004) Spatiotemporal control of gene expression with pulse-generating networks. Proceedings of the National Academy of Sciences of the United States of America 101:6355-6360.

BEAL J, WEISS R, DENSMORE D, ADLER A, APPLETON E, BABB J, BHATIA S, DAVIDSOHN N, HADDOCK T, LOYALL J (2012) An Endto-End Workflow for Engineering of Biological Networks from HighLevel Specifications. ACS Synthetic Biology 1:317-331.

BECSKEI A, SERRANO L (2000) Engineering stability in gene networks by autoregulation. Nature 405:590-593.

BENENSON Y (2011) Biocomputing: DNA computes a square root. Nature Nanotechnology 6:465-467.

BENENSON Y (2012) Biomolecular computing systems: principles, progress and potential.. Nat Rev Genet 13:455-68.

BENNETT MR, HASTY J (2009) Microfluidic devices for measuring gene network dynamics in single cells. Nature Reviews Genetics 10:628-638.

BERTHOUMIEUX S, DE JONG H, BAPTIST G, PINEL C, RANQUET C, ROPERS D, GEISELMANN J (2013) Shared control of gene expression in bacteria by transcription factors and global physiology of the cell. Molecular Systems Biology 9:

BLAKE WJ, KAERN M, CANTOR CR, COLLINS JJ (2003) Noise in eukaryotic gene expression.. Nature 422:633-7.

BLOUNT BA, WEENINK T, VASYLECHKO S, ELLIS T (2012) Rational diversification of a promoter providing fine-tuned expression and orthogonal regulation for synthetic biology.. PLoS One 7:e33279.

BOCH J, SCHOLZE H, SCHORNACK S, LANDGRAF A, HAHN S, KAY S, LAHAYE T, NICKSTADT A, BONAS U (2009) Breaking the code of DNA binding specificity of TAL-type III effectors. Science 326:1509-1512.

BONABEAU E, DORIGO M, THERAULAZ G (2000) Inspiration for optimization from social insect behaviour. Nature 406:39-42.

BONGARD J, LIPSON H (2007) Automated reverse engineering of nonlinear dynamical systems. Proceedings of the National Academy of Sciences 104:9943.

BONGARD J, ZYKOV V, LIPSON H (2006) Resilient machines through continuous self-modeling. Science 314:1118-1121.

BONNET J, SUBSOONTORN P, ENDY D (2012) Rewritable digital data storage in live cells via engineered control of recombination directionality. Proceedings of the National Academy of Sciences 109:8884-8889.

BONNET J, YIN P, ORTIZ ME, SUBSOONTORN P, ENDY D (2013) Amplifying Genetic Logic Gates.. Science 340:599-603.

BOUDAOUD A (2010) An introduction to the mechanics of morphogenesis for plant biologists.. Trends Plant Sci 15:353-60.

BOYER D, MATHER W, MONDRAGÓN-PALOMINO O, OROZCOFUENTES S, DANINO T, HASTY J, TSIMRING LS (2011) Buckling instability in ordered bacterial colonies.. Phys Biol 8:026008.

BRAY D (2003) Molecular networks: the top-down view. Science 301:1864-1865.

BRENNER K, ARNOLD FH (2011) Self-organization, layered structure, and aggregation enhance persistence of a synthetic biofilm consortium. PloS one 6:e16791.

BRENNER K, KARIG DK, WEISS R, ARNOLD FH (2007) Engineered bidirectional communication mediates a consensus in a microbial biofilm consortium.. Proc Natl Acad Sci U S A 104:17300-4.

BRENNER K, YOU L, ARNOLD FH (2008) Engineering microbial consortia: a new frontier in synthetic biology. Trends in biotechnology 26:483-489.

BULTER T, LEE S-G, WONG WW, FUNG E, CONNOR MR, LIAO JC (2004) Design of artificial cell--cell communication using gene and metabolic networks. Proceedings of the National Academy of Sciences of the United States of America 101:2299-2304.

CAMBRAY G, GUIMARAES JC, MUTALIK VK, LAM C, MAI Q-A, THIMMAIAH T, CAROTHERS JM, ARKIN AP, ENDY D (2013) 
Measurement and modeling of intrinsic transcription terminators. Nucleic acids research 41:5139-5148.

CANTON B, LABNO A, ENDY D (2008) Refinement and standardization of synthetic biological parts and devices.. Nat Biotechnol 26:787-93.

CANTONE I, MARUCCI L, IORIO F, RICCI MA, BELCASTRO V, BANSAL $\mathrm{M}$, SANTINI S, DI BERNARDO M, DI BERNARDO D, COSMA MP (2009) A yeast synthetic network for in vivo assessment of reverseengineering and modeling approaches.. Cell 137:172-81.

CARDINALE S, ARKIN AP (2012) Contextualizing context for synthetic biology--identifying causes of failure of synthetic biological systems. Biotechnology journal 7:856-866.

CARLSON R (2009) The changing economics of DNA synthesis. Nature biotechnology 27:1091.

CHANDRAN D, SAURO HM (2012) Hierarchical modeling for synthetic biology. ACS Synthetic Biology 1:353-364.

CHEN M-T, WEISS R (2005) Artificial cell-cell communication in yeast Saccharomyces cerevisiae using signaling elements from Arabidopsis thaliana. Nature biotechnology 23:1551-1555.

CHIN JW (2012) Molecular biology. Reprogramming the genetic code.. Science 336:428-9.

CHOW BY, BOYDEN ES (2011) Synthetic Physiology. Science Signaling 332:1508.

CHUANG JS (2012) Engineering multicellular traits in synthetic microbial populations.. Curr Opin Chem Biol 16:370-8.

CHUANG JS, RIVOIRE O, LEIBLER S (2009) Simpson's paradox in a synthetic microbial system. Science 323:272-275.

CHUANG JS, RIVOIRE O, LEIBLER S (2010) Cooperation and Hamilton's rule in a simple synthetic microbial system.. Mol Syst Biol 6:398.

CHURCH GM, GAO Y, KOSURI S (2012) Next-generation digital information storage in DNA.. Science 337:1628.

COHEN-SAIDON C, COHEN AA, SIGAL A, LIRON Y, ALON U (2009) Dynamics and variability of ERK2 response to EGF in individual living cells. Molecular cell 36:885-893.

COOKSON NA, MATHER WH, DANINO T, MONDRAGÓN-PALOMINO O, WILLIAMS RJ, TSIMRING LS, HASTY J (2011) Queueing up for enzymatic processing: correlated signaling through coupled degradation. Molecular systems biology 7:

COTTERELL J, SHARPE J (2010) An atlas of gene regulatory networks reveals multiple three-gene mechanisms for interpreting morphogen gradients. Molecular systems biology 6:

ÇA \UGATAY T, TURCOTTE M, ELOWITZ MB, GARCIA-OJALVO J, SÜEL GM (2009) Architecture-dependent noise discriminates functionally analogous differentiation circuits.. Cell 139:512.

DALLARD P, FITZPATRICK T, FLINT A, LOW A, SMITH RR, WILLFORD M, ROCHE M (2001) London Millennium Bridge: pedestrian-induced lateral vibration. Journal of Bridge Engineering 6:412-417.

DAMLE SS, DAVIDSON EH (2012) Synthetic in vivo validation of gene network circuitry.. Proc Natl Acad Sci U S A 109:1548-53.

DANINO T, MONDRAGÓN-PALOMINO O, TSIMRING L, HASTY J (2010) A synchronized quorum of genetic clocks. Nature 463:326-330.

DAVIDSON EH (2010) Emerging properties of animal gene regulatory networks.. Nature 468:911-20.

DAVIS JH, RUBIN AJ, SAUER RT (2011) Design, construction and characterization of a set of insulated bacterial promoters. Nucleic acids research 39:1131-1141.

DENSMORE D (2012) Bio-Design Automation: Nobody Said It Would Be Easy. ACS Synthetic Biology 1:296-296.

DOUGLAS SM, BACHELET I, CHURCH GM (2012) A logic-gated nanorobot for targeted transport of molecular payloads.. Science 335:831-4.

DUEBER JE, YEH BJ, CHAK K, LIM WA (2003) Reprogramming control of an allosteric signaling switch through modular recombination. Science Signaling 301:1904.

ELLIS T, ADIE T, BALDWIN GS (2011) DNA assembly for synthetic biology: from parts to pathways and beyond. Integrative Biology 3:109-118.

ELOWITZ MB, LEVINE AJ, SIGGIA ED, SWAIN PS (2002) Stochastic gene expression in a single cell.. Science 297:1183-6.

ELOWITZ M, LIM WA (2010) Build life to understand it.. Nature 468:889-90.

ENDY D (2005) Foundations for engineering biology. Nature 438:449-453.

ESPINOSA-SOTO C, PADILLA-LONGORIA P, ALVAREZ-BUYLLA ER (2004) A gene regulatory network model for cell-fate determination during Arabidopsis thaliana flower development that is robust and recovers experimental gene expression profiles.. Plant Cell 16:2923-39.

ESPINOSA-SOTO C, WAGNER A (2010) Specialization can drive the evolution of modularity. PLoS computational biology 6:e1000719.

ESVELT KM, WANG HH (2013) Genome-scale engineering for systems and synthetic biology.. Mol Syst Biol 9:641.
FARZADFARD F, PERLI SD, LU T. (2013) Tunable and Multifunctional Eukaryotic Transcription Factors Based on CRISPR/Cas. ACS Synth Biol. Sep 11.

FEDERICI F, DUPUY L, LAPLAZE L, HEISLER M, HASELOFF J (2012) Integrated genetic and computation methods for in planta cytometry.. Nat Methods 9:483-5.

FERRELL JR JE (2002) Self-perpetuating states in signal transduction: positive feedback, double-negative feedback and bistability. Current opinion in cell biology 14:140-148.

FRATZL P (2007) Biomimetic materials research: what can we really learn from nature's structural materials?. Journal of the Royal Society Interface 4:637-642.

GALLOIS JL, NORA FR, MIZUKAMI Y, SABLOWSKI R (2004) WUSCHEL induces shoot stem cell activity and developmental plasticity in the root meristem.. Genes Dev 18:375-80.

GARDNER TS, CANTOR CR, COLLINS JJ (2000) Construction of a genetic toggle switch inEscherichia coli. Nature 403:339-342.

GARG A, LOHMUELLER JJ, SILVER PA, ARMEL TZ (2012) Engineering synthetic TAL effectors with orthogonal target sites. Nucleic acids research 40:7584-7595.

GIBSON DG, GLASS JI, LARTIGUE C, NOSKOV VN, CHUANG RY, ALGIRE MA, BENDERS GA, MONTAGUE MG, MA L, MOODIE MM, MERRYMAN C, VASHEE S, KRISHNAKUMAR R, ASSAD-GARCIA N, ANDREWS-PFANNKOCH C, DENISOVA EA, YOUNG L, QI ZQ, SEGALL-SHAPIRO TH, CALVEY CH, PARMAR PP, HUTCHISON CA, SMITH HO, VENTER JC (2010) Creation of a bacterial cell controlled by a chemically synthesized genome.. Science 329:52-6.

GIBSON DG, YOUNG L, CHUANG RY, VENTER JC, HUTCHISON CA, SMITH HO (2009) Enzymatic assembly of DNA molecules up to several hundred kilobases.. Nat Methods 6:343-5.

GIERER A, MEINHARDT H (1972) A theory of biological pattern formation.. Kybernetik 12:30-9.

GILLESPIE DT (1977) Exact stochastic simulation of coupled chemical reactions. The journal of physical chemistry 81:2340-2361.

GOENTORO L, KIRSCHNER MW (2009) Evidence that fold-change, and not absolute level, of beta-catenin dictates Wnt signaling.. Mol Cell 36:872-84.

GOENTORO L, SHOVAL O, KIRSCHNER MW, ALON U (2009) The incoherent feedforward loop can provide fold-change detection in gene regulation.. Mol Cell 36:894-9.

GRÜNBERG R, SERRANO L (2010) Strategies for protein synthetic biology. Nucleic acids research 38:2663-2675.

HAMMER DA, KAMAT NP (2012) Towards an artificial cell.. FEBS Lett 586:2882-90.

HARTWELL LH, HOPFIELD JJ, LEIBLER S, MURRAY AW (1999) From molecular to modular cell biology. Nature 402:C47-C52.

HILFINGER A, PAULSSON J (2011) Separating intrinsic from extrinsic fluctuations in dynamic biological systems. Proceedings of the National Academy of Sciences 108:12167-12172.

HOPFIELD JJ (1982) Neural networks and physical systems with emergent collective computational abilities. Proceedings of the national academy of sciences 79:2554-2558.

ISAACS FJ, HASTY J, CANTOR CR, COLLINS JJ (2003) Prediction and measurement of an autoregulatory genetic module.. Proc Natl Acad Sci U S A 100:7714-9.

ISALAN M, LEMERLE C, MICHALODIMITRAKIS K, HORN C, BELTRAO P, RAINERI E, GARRIGA-CANUT M, SERRANO L (2008) Evolvability and hierarchy in rewired bacterial gene networks.. Nature 452:840-5.

JACOB F, MONOD J (1961) Genetic regulatory mechanisms in the synthesis of proteins. Journal of molecular biology 3:318-356.

JEONG H, TOMBOR B, ALBERT R, OLTVAI ZN, BARABÁSI A-L (2000) The large-scale organization of metabolic networks. Nature 407:651-654.

JIANG L, ALTHOFF EA, CLEMENTE FR, DOYLE L, RÖTHLISBERGER D, ZANGHELLINI A, GALLAHER JL, BETKER JL, TANAKA F, BARBAS CF (2008) De novo computational design of retro-aldol enzymes. science 319:1387-1391.

DE JONG H, RANQUET C, ROPERS D, PINEL C, GEISELMANN J (2010) Experimental and computational validation of models of fluorescent and luminescent reporter genes in bacteria.. BMC Syst Biol 4:55.

KASHTAN N, ALON U (2005) Spontaneous evolution of modularity and network motifs. Proceedings of the National Academy of Sciences of the United States of America 102:13773-13778.

KAUFFMAN SA (1969) Metabolic stability and epigenesis in randomly constructed genetic nets. Journal of theoretical biology 22:437-467.

KELLY JR, RUBIN AJ, DAVIS JH, AJO-FRANKLIN CM, CUMBERS J, CZAR MJ, DE MORA K, GLIEBERMAN AL, MONIE DD, ENDY D (2009) 
Measuring the activity of BioBrick promoters using an in vivo reference standard.. J Biol Eng 3:4.

KEMMER C, GITZINGER M, DAOUD-EL BABA M, DJONOV V, STELLING J, FUSSENEGGER M (2010) Self-sufficient control of urate homeostasis in mice by a synthetic circuit. Nature biotechnology 28:355-360.

KHALIL AS, COLLINS JJ (2010) Synthetic biology: applications come of age. Nature Reviews Genetics 11:367-379.

KHALIL AS, LU TK, BASHOR CJ, RAMIREZ CL, PYENSON NC, JOUNG JK, COLLINS JJ (2012) A synthetic biology framework for programming eukaryotic transcription functions.. Cell 150:647-58.

KICHEVA A, COHEN M, BRISCOE J (2012) Developmental pattern formation: insights from physics and biology.. Science 338:210-2.

KITANO H (2007) Towards a theory of biological robustness. Molecular systems biology 3 :

KLUMPP S, ZHANG Z, HWA T (2009) Growth rate-dependent global effects on gene expression in bacteria. Cell 139:1366-1375.

KNIGHT T, RETTBERG R, CHAN L, ENDY D, SHETTY R, CHE A Idempotent vector design for standard assembly of biobricks. 2003. DSpace@MIT

KOSURI S, GOODMAN DB, CAMBRAY G, MUTALIK VK, GAO Y, ARKIN AP, ENDY D, CHURCH GM Kosuri S (2013) Composability of regulatory sequences controlling transcription and translation in Escherichia coli.. Proc Natl Acad Sci U S A. 110(34):14024-9. LANZA AM, CROOK NC, ALPER HS (2012) Innovation at the intersection of synthetic and systems biology.. Curr Opin Biotechnol 23:712-7.

LAUFFENBURGER DA (2000) Cell signaling pathways as control modules: Complexity for simplicity?. Proceedings of the National Academy of Sciences 97:5031-5033.

LEVEAU JH, LINDOW SE (2001) Predictive and interpretive simulation of green fluorescent protein expression in reporter bacteria.. J Bacteriol 183:6752-62.

LEVSKAYA A, CHEVALIER AA, TABOR JJ, SIMPSON ZB, LAVERY LA, LEVY M, DAVIDSON EA, SCOURAS A, ELLINGTON AD, MARCOTTE EM, VOIGT CA (2005) Synthetic biology: Engineering Escherichia coli to see light. 438:441-442.

LI F, LONG T, LU Y, OUYANG Q, TANG C (2004) The yeast cell-cycle network is robustly designed. Proceedings of the National Academy of Sciences of the United States of America 101:4781-4786.

LIM WA, LEE CM, TANG C (2013) Design principles of regulatory networks: searching for the molecular algorithms of the cell.. Mol Cell 49:202-12.

LIPSON H (2007) Principles of modularity, regularity, and hierarchy for scalable systems. Journal of Biological Physics and Chemistry 7:125.

LIU AP, FLETCHER DA (2009) Biology under construction: in vitro reconstitution of cellular function.. Nat Rev Mol Cell Biol 10:644-50.

LIU C, FU X, LIU L, REN X, CHAU CKL, LI S, XIANG L, ZENG H, CHEN G, TANG LH (2011) Sequential establishment of stripe patterns in an expanding cell population. Science Signalling 334:238.

LIU CC, QI L, LUCKS JB, SEGALL-SHAPIRO TH, WANG D, MUTALIK VK, ARKIN AP (2012) An adaptor from translational to transcriptional control enables predictable assembly of complex regulation.. Nat Methods 9:1088-94

LONG Z, NUGENT E, JAVER A, CICUTA P, SCLAVI B, LAGOMARSINO MC, DORFMAN KD (2013) Microfluidic chemostat for measuring single cell dynamics in bacteria. Lab on a Chip 13:947-954.

LOU C, STANTON B, CHEN YJ, MUNSKY B, VOIGT CA (2012) Ribozymebased insulator parts buffer synthetic circuits from genetic context.. Nat Biotechnol 30:1137-42.

LU TK, KHALIL AS, COLLINS JJ (2009) Next-generation synthetic gene networks. Nature biotechnology 27:1139-1150.

MA W, TRUSINA A, EL-SAMAD H, LIM WA, TANG C (2009) Defining network topologies that can achieve biochemical adaptation. Cell 138:760-773.

MAAMAR H, RAJ A, DUBNAU D (2007) Noise in gene expression determines cell fate in Bacillus subtilis. Science Signaling 317:526.

MANSY SS, SCHRUM JP, KRISHNAMURTHY M, TOBÉ S, TRECO DA, SZOSTAK JW (2008) Template-directed synthesis of a genetic polymer in a model protocell.. Nature 454:122-5.

MCADAMS HH, ARKIN A (2000) Gene regulation: Towards a circuit engineering discipline. Current Biology 10:R318-R320.

MCADAMS HH, SHAPIRO L (1995) Circuit simulation of genetic networks. Science 269:650-656.

MCEWEN JT, ATSUMI S (2012) Alternative biofuel production in nonnatural hosts. Current Opinion in Biotechnology 23:744-750.

MENDOZA L, THIEFFRY D, ALVAREZ-BUYLLA ER (1999) Genetic control of flower morphogenesis in Arabidopsis thaliana: a logical analysis.. Bioinformatics 15:593-606.
MILO R, SHEN-ORR S, ITZKOVITZ S, KASHTAN N, CHKLOVSKII D, ALON U (2002) Network motifs: simple building blocks of complex networks.. Science 298:824-7.

MIYAMOTO T, RAZAVI S, DEROSE R, INOUE T (2012) Synthesizing Biomolecule-Based Boolean Logic Gates. ACS Synthetic Biology 2:72-82.

MOON TS, LOU C, TAMSIR A, STANTON BC, VOIGT CA (2012) Genetic programs constructed from layered logic gates in single cells.. Nature 491:249-53.

MUKHERJI S, VAN OUDENAARDEN A (2009) Synthetic biology: understanding biological design from synthetic circuits. Nature Reviews Genetics 10:859-871.

MUNSKY B, KHAMMASH M (2006) The finite state projection algorithm for the solution of the chemical master equation. The Journal of Chemical Physics 124:044104.

MUNSKY B, NEUERT G, VAN OUDENAARDEN A (2012) Using gene expression noise to understand gene regulation.. Science 336:183-7.

MUTALIK VK, GUIMARAES JC, CAMBRAY G, LAM C, CHRISTOFFERSEN MJ, MAI QA, TRAN AB, PAULL M, KEASLING JD, ARKIN AP, ENDY D (2013a) Precise and reliable gene expression via standard transcription and translation initiation elements.. Nat Methods 10:354-60.

MUTALIK VK, GUIMARAES JC, CAMBRAY G, MAI QA, CHRISTOFFERSEN MJ, MARTIN L, YU A, LAM C, RODRIGUEZ C, BENNETT G, KEASLING JD, ENDY D, ARKIN AP (2013b) Quantitative estimation of activity and quality for collections of functional genetic elements.. Nat Methods 10:347-53.

NANDAGOPAL N, ELOWITZ MB (2011) Synthetic biology: integrated gene circuits. science 333:1244-1248.

NEUBAUER P, LIN HY, MATHISZIK B (2003) Metabolic load of recombinant protein production: inhibition of cellular capacities for glucose uptake and respiration after induction of a heterologous gene in Escherichia coli. Biotechnology and bioengineering 83:53-64.

NEUERT G, MUNSKY B, TAN RZ, TEYTELMAN L, KHAMMASH M, VAN OUDENAARDEN A (2013) Systematic identification of signal-activated stochastic gene regulation.. Science 339:584-7.

NIEHRS C, MEINHARDT H (2002) Developmental biology: Modular feedback. Nature 417:35-36.

NURSE P (2008) Life, logic and information. Nature 454:424-426.

OZBUDAK EM, THATTAI M, LIM HN, SHRAIMAN BI, VAN OUDENAARDEN A (2004) Multistability in the lactose utilization network of Escherichia coli. Nature 427:737-740.

PEDRAZA JM, VAN OUDENAARDEN A (2005) Noise propagation in gene networks.. Science 307:1965-9.

PERALES M, REDDY GV (2012) Stem cell maintenance in shoot apical meristems. Current opinion in plant biology 15:10-16.

PETER IS, FAURE E, DAVIDSON EH (2012) Predictive computation of genomic logic processing functions in embryonic development.. Proc Natl Acad Sci U S A 109:16434-42.

PODHAJSKA AJ, HASAN N, SZYBALSKI W (1985) Control of cloned gene expression by promoter inversion in vivo: construction of the heatpulseactivated $<$ i $>$ att-nut $\mathrm{L}-<\mathrm{i}>\mathrm{p}-<\mathrm{i}>$ att $-<\mathrm{i}>\mathrm{N}$ module. Gene 40:163168.

PURNICK PE, WEISS R (2009) The second wave of synthetic biology: from modules to systems. Nature Reviews Molecular Cell Biology 10:410-422.

QI L, HAURWITZ RE, SHAO W, DOUDNA JA, ARKIN AP (2012) RNA processing enables predictable programming of gene expression.. Nat Biotechnol 30:1002-6.

QIAN L, WINFREE E (2011) Scaling Up Digital Circuit Computation with DNA Strand Displacement Cascades. Science 332:1196-1201.

RAMIZ D, RUBENS JR, SARPESHKAR R, LU TK. (2013) Synthetic analog computation in living cells. Nature, 497(7451):619-623.

REGOT S, MACIA J, CONDE N, FURUKAWA K, KJELLÉN J, PEETERS T, HOHMANN S, DE NADAL E, POSAS F, SOLÉ R (2011) Distributed biological computation with multicellular engineered networks.. Nature 469:207-11.

RINAUDO K, BLERIS L, MADDAMSETTI R, SUBRAMANIAN S, WEISS R, BENENSON Y (2007) A universal RNAi-based logic evaluator that operates in mammalian cells. Nature biotechnology 25:795-801.

RO D-K, PARADISE EM, OUELLET M, FISHER KJ, NEWMAN KL, NDUNGU JM, HO KA, EACHUS RA, HAM TS, KIRBY J (2006) Production of the antimalarial drug precursor artemisinic acid in engineered yeast. Nature 440:940-943.

RODRIGO G, CARRERA J, JARAMILLO A (2011) Computational design of synthetic regulatory networks from a genetic library to characterize the designability of dynamical behaviors. Nucleic Acids Research 39:e138-e138.

RODRIGO G, LANDRAIN TE, JARAMILLO A (2012) De novo automated design of small RNA circuits for engineering synthetic riboregulation in 
living cells. Proceedings of the National Academy of Sciences 109:1527115276.

RÖTHLISBERGER D, KHERSONSKY O, WOLLACOTT AM, JIANG L, DECHANCIE J, BETKER J, GALLAHER JL, ALTHOFF EA, ZANGHELLINI A, DYM O (2008) Kemp elimination catalysts by computational enzyme design. Nature 453:190-195.

RUDER WC, LU T, COLLINS JJ (2011) Synthetic biology moving into the clinic. Science 333:1248-1252.

RUDGE TJ, STEINER PJ, PHILLIPS A, HASELOFF J (2012) Computational modeling of synthetic microbial biofilms. ACS Synthetic Biology 1:345-352.

SAEIDI N, WONG CK, LO T-M, NGUYEN HX, LING H, LEONG SSJ, POH CL, CHANG MW (2011) Engineering microbes to sense and eradicate Pseudomonas aeruginosa, a human pathogen. Molecular systems biology 7:

SALIS HM, MIRSKY EA, VOIGT CA (2009) Automated design of synthetic ribosome binding sites to control protein expression. Nature biotechnology 27:946-950.

SAMOILOV MS, ARKIN AP (2006) Deviant effects in molecular reaction pathways. Nature biotechnology 24:1235-1240.

SCHAMEL WW, RETH M (2012) Synthetic immune signaling. Current Opinion in Biotechnology 23:780-784.

SCHMIDT M, LIPSON H (2009) Distilling free-form natural laws from experimental data. science 324:81.

SCHMIDT MD, VALLABHAJOSYULA RR, JENKINS JW, HOOD JE, SONI AS, WIKSWO JP, LIPSON H (2011) Automated refinement and inference of analytical models for metabolic networks. Physical Biology 8:055011.

SEKINE R, YAMAMURA M, AYUKAWA S, ISHIMATSU K, AKAMA S, TAKINOUE M, HAGIYA M, KIGA D (2011) Tunable synthetic phenotypic diversification on Waddington's landscape through autonomous signaling. Proceedings of the National Academy of Sciences 108:17969-17973.

SHEN-ORR SS, MILO R, MANGAN S, ALON U (2002) Network motifs in the transcriptional regulation network of Escherichia coli. Nature genetics 31:64-68.

SHETTY RP, ENDY D, KNIGHT TF (2008) Engineering BioBrick vectors from BioBrick parts.. J Biol Eng 2:5.

SHINAR G, FEINBERG M (2010) Structural sources of robustness in biochemical reaction networks.. Science 327:1389-91.

SHONG J, JIMENEZ DIAZ MR, COLLINS CH (2012) Towards synthetic microbial consortia for bioprocessing. Current Opinion in Biotechnology 23:798-802.

SHOU W, RAM S, VILAR JMG (2007) Synthetic cooperation in engineered yeast populations. Proceedings of the National Academy of Sciences 104:1877-1882.

SIUTI P, YAZBEK J, LU TK (2013) Synthetic circuits integrating logic and memory in living cells.. Nat Biotechnol 31:448-52.

SMOLKE CD (2009) Building outside of the box: iGEM and the BioBricks Foundation. Nature biotechnology 27:1099-1102.

SMOLKE CD, SILVER PA (2011) Informing biological design by integration of systems and synthetic biology.. Cell 144:855-9.

SO L-H, GHOSH A, ZONG C, SEPÚLVEDA LA, SEGEV R, GOLDING I (2011) General properties of transcriptional time series in Escherichia coli. Nature genetics 43:554-560.

STELLING J, SAUER U, SZALLASI Z, III FJD, DOYLE J (2004) Robustness of Cellular Functions. Cell 118:675 - 685

SUGITA M (1963) Functional analysis of chemical systems $<$ i $>$ in vivo using a logical circuit equivalent. II. The idea of a molecular automaton. Journal of Theoretical Biology 4:179-192.

SÜEL GM, GARCIA-OJALVO J, LIBERMAN LM, ELOWITZ MB (2006) An excitable gene regulatory circuit induces transient cellular differentiation.. Nature 440:545-50.

SWAIN PS, ELOWITZ MB, SIGGIA ED (2002) Intrinsic and extrinsic contributions to stochasticity in gene expression. Proceedings of the National Academy of Sciences 99:12795-12800.

TABOR JJ, LEVSKAYA A, VOIGT CA (2011) Multichromatic Control of Gene Expression in $<\mathrm{i}>$ Escherichia coli. Journal of molecular biology 405:315-324.

TABOR JJ, SALIS HM, SIMPSON ZB, CHEVALIER AA, LEVSKAYA A, MARCOTTE EM, VOIGT CA, ELLINGTON AD (2009) A synthetic genetic edge detection program.. Cell 137:1272-81.
TAMSIR A, TABOR JJ, VOIGT CA (2010) Robust multicellular computing using genetically encoded NOR gates and chemical/wires/'. Nature 469:212-215.

TANOUCHI Y, SMITH RP, YOU L (2012) Engineering microbial systems to explore ecological and evolutionary dynamics. Current Opinion in Biotechnology 23:791-797.

TEMME K, ZHAO D, VOIGT CA (2012) Refactoring the nitrogen fixation gene cluster from Klebsiella oxytoca.. Proc Natl Acad Sci U S A 109:7085-90.

TERO A, TAKAGI S, SAIGUSA T, ITO K, BEBBER DP, FRICKER MD, YUMIKI K, KOBAYASHI R, NAKAGAKI T (2010) Rules for biologically inspired adaptive network design.. Science 327:439-42.

THOMAS R (1973) Boolean formalization of genetic control circuits. Journal of theoretical biology 42:563-585.

TURING AM (1952) The chemical basis of morphogenesis. Philosophical Transactions of the Royal Society of London. Series B, Biological Sciences 237:37-72.

VAN DER SLOOT AM, KIEL C, SERRANO L, STRICHER F (2009) Protein design in biological networks: from manipulating the input to modifying the output. Protein Engineering Design and Selection 22:537-542.

VILAR JM (2006) Modularizing gene regulation. Molecular Systems Biology 2:

VOLFSON D, COOKSON S, HASTY J, TSIMRING LS (2008) Biomechanical ordering of dense cell populations. Proceedings of the National Academy of Sciences 105:15346-15351.

VON DASSOW G, MEIR E, MUNRO EM, ODELL GM (2000) The segment polarity network is a robust developmental module. Nature 406:188-192.

WANG B, BARAHONA M, BUCK M (2013) A modular cell-based biosensor using engineered genetic logic circuits to detect and integrate multiple environmental signals.. Biosens Bioelectron 40:368-76.

WANG W-D, CHEN Z-T, KANG B-G, LI R (2008) Construction of an artificial intercellular communication network using the nitric oxide signaling elements in mammalian cells.. Experimental cell research 314:699.

WANG P, ROBERT L, PELLETIER J, DANG WL, TADDEI F, WRIGHT A, JUN S (2010) Robust Growth of $<\mathrm{i}>$ Escherichia coli. Current biology 20:1099-1103.

WEBER W, BABA DE, FUSSENEGGER M (2007a) Synthetic ecosystems based on airborne inter-and intrakingdom communication. Proceedings of the National Academy of Sciences 104:10435-10440.

WEBER W, DAOUD-EL BABA M, FUSSENEGGER M (2007b) Synthetic ecosystems based on airborne inter- and intrakingdom communication.. Proc Natl Acad Sci U S A 104:10435-40.

WEBER W, FUSSENEGGER M (2011) Emerging biomedical applications of synthetic biology. Nature Reviews Genetics

WEISS R, BASU S, HOOSHANGI S, KALMBACH A, KARIG D, MEHREJA R, NETRAVALI I (2003) Genetic circuit building blocks for cellular computation, communications, and signal processing. Natural Computing 2:47-84.

WENG G, BHALLA US, IYENGAR R (1999) Complexity in biological signaling systems. Science 284:92-96.

WIN MN, SMOLKE CD (2008) Higher-order cellular information processing with synthetic RNA devices.. Science 322:456-60.

WINTERMUTE EH, SILVER PA (2010) Dynamics in the mixed microbial concourse. Genes \& development 24:2603-2614.

WU H-C, TSAO C-Y, QUAN DN, CHENG Y, SERVINSKY MD, CARTER KK, JEE KJ, TERRELL JL, ZARGAR A, RUBLOFF GW (2013) Autonomous bacterial localization and gene expression based on nearby cell receptor density. Molecular systems biology 9 :

YAMAN F, BHATIA S, ADLER A, DENSMORE D, BEAL J (2012) Automated selection of synthetic biology parts for genetic regulatory networks. ACS Synth Biol 1:332-44.

YI T-M, HUANG Y, SIMON MI, DOYLE J (2000) Robust perfect adaptation in bacterial chemotaxis through integral feedback control. Proceedings of the National Academy of Sciences 97:4649-4653.

YOU L, COX RS, WEISS R, ARNOLD FH (2004) Programmed population control by cell-cell communication and regulated killing.. Nature 428:868-71. 
